\title{
A paleolimnological archive of metal sequestration and release in the Cumberland Basin Marshes, Atlantic Canada
}

\author{
Dewey W. Dunnington $^{\mathrm{a} \star}$, Hilary White ${ }^{\mathrm{ab}}$, Ian S. Spooner ${ }^{\mathrm{a}}$, Mark L. Mallory ${ }^{\mathrm{c}}$, Chris White ${ }^{\mathrm{d}}$, \\ Nelson J. O'Driscoll ${ }^{\mathrm{a}}$, and Nic R. McLellan ${ }^{\mathrm{e}}$ \\ ${ }^{a}$ Department of Earth and Environmental Science, Acadia University, Wolfville, NS B4P 2R6, Canada; \\ ${ }^{b}$ Department of Geography and Environmental Studies, Wilfrid Laurier University, Waterloo, ON N2L 3C5, \\ Canada; ${ }^{\mathrm{C}}$ Department of Biology, Acadia University, Wolfville, NS B4P 2R6, Canada; ${ }^{\mathrm{d}}$ Nova Scotia \\ Department of Natural Resources, P.O. Box 698, Halifax, NS B3J 2T9, Canada; ${ }^{ }$Nova Scotia Provincial \\ Office, Ducks Unlimited Canada, P.O. Box 430, Amherst, NS B4H 3Z5, Canada \\ *088823d@acadiau.ca
}

\section{OPEN ACCESS}

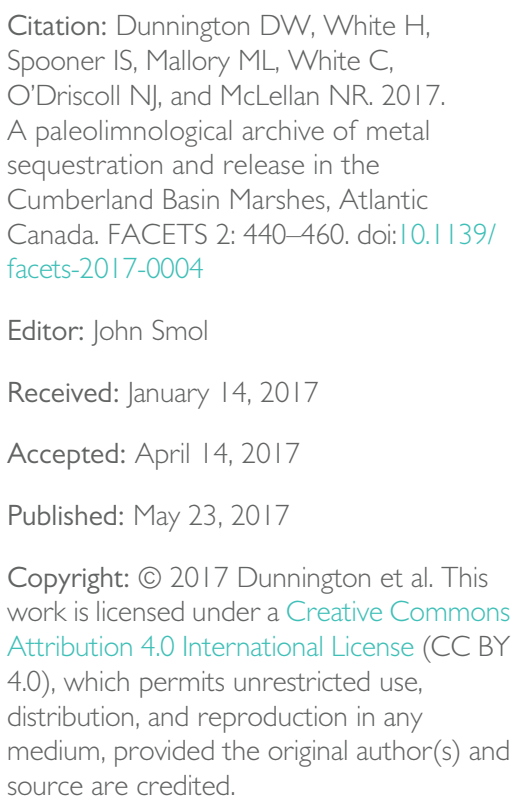

Published by: Canadian Science Publishing

\begin{abstract}
We used a paleolimnological approach at Long Lake, Nova Scotia, to construct a 10500 -year record of metal deposition in lakebed sediments and elucidate the influence of both natural and anthropogenic environmental changes. Aquatic sediment concentrations of mercury ( $\mathrm{Hg}$ ), arsenic (As), and chromium (Cr) in Long Lake fluctuated substantially and, during some periods, exceeded guidelines for the protection of aquatic life. Increases in lead $(\mathrm{Pb}), \mathrm{Hg}, \mathrm{Cr}$, trace metals, and nitrogen stable isotopes $\left(\delta^{15} \mathrm{~N}\right)$ were broadly coincident with a period of widespread drying from ca. 8000 to $4000 \mathrm{cal} \mathrm{BP}$ and were likely a consequence of regional fires. From ca. $4000 \mathrm{cal}$ BP until 1700 AD, metal levels in general were low due to decreased erosion, increased precipitation, and reduced fire activity. Water level lowering and forced sediment aggradation (tiding) in the 1800s led to increases in minerogenic $\mathrm{Pb}$ and $\mathrm{Cr}$, though fossil fuel combustion also likely contributed to total $\mathrm{Pb}$ concentrations. Stratigraphic proxies indicated increased inorganic sedimentation rates, and reduced autochthonous productivity were coincident with lower $\mathrm{Hg}$ and As concentrations in the Long Lake sediment. Our data indicate that natural phenomena (fire) can result in sediment contaminant exceedances, that most metals have multiple sources, and that both human-induced disturbance and emissions have contributed to $\mathrm{Pb}$ contamination in the last 200 years. In addition, wetter and generally cooler climate appeared to favour lower concentrations of contaminants in lake sediments. Although wetland sediments in the Cumberland Basin Marshes are not heavily polluted with metals, the development of constructed wetlands and the disruption of aquatic sediments have the potential to concentrate, mobilize, and increase the bioavailability of metals.
\end{abstract}

Key words: metal sequestration, wetlands, paleolimnology, Tantramar Marshes

\section{Introduction}

Estuarine environments are important environments supporting both coastal and marine food webs, yet many have been modified by anthropogenic activity (Euliss et al. 1999; Sharitz and Batzer 1999; Scott et al. 2014; Mitsch and Gosselink 2015; Loder et al. 2016). The ecological value of coastal 
wetlands within estuarine environments has long been recognized, and mitigating the effects of metal accumulation from natural and anthropogenic sources is a primary objective of many wetland managers (e.g., Englehardt 2013; Loder et al. 2016). In particular, the identification of metal sources, the potential for these metals to be sequestered or released into the environment, and management practices that mitigate further effects on wildlife are important areas of research.

The Cumberland Marsh Region (CMR) is a macrotidal estuarine environment located in the upper Bay of Fundy (Chmura et al. 2001; Shaw et al. 2010). The CMR is located within the Atlantic migratory flyway and has been the focus of significant wildlife conservation and wetland restoration efforts in eastern North America. At 20230 ha, the marsh is one of the largest on the Atlantic coast of North America and is an important stopover for migrating waterfowl. Although the CMR has a 300-year history of anthropogenic alteration, it still contains productive waterfowl habitat consisting of salt marshes, brackish wetlands, constructed wetlands, and lakes (Austin-Smith and Bowes 2000; Davis and Browne 2002; Dunnington 2011). Much of the habitat in the region is managed by provincial and national authorities in conjunction with Ducks Unlimited Canada (DUC) (MacDonald and Clowater 2005; White 2012).

Lead $(\mathrm{Pb})$, arsenic $(\mathrm{As})$, and mercury $(\mathrm{Hg})$ are metals that bioaccumulate in various inorganic and organic forms, are toxic to waterfowl and marsh birds and, in the CMR, occur in lakebed sediments at levels that may exceed the Canadian interim sediment quality guidelines for the protection of aquatic life (Adler 1944; Canadian Council of Ministers for the Environment (CCME) 1999; Loder et al. 2016). Although atmospheric deposition (Weiss et al. 2002; Sullyman 2003; O'Driscoll et al. 2005), lead shot (Schwab and Daury 1989), and till (Dummer et al. 2015) have been recognized as possible sources of these elements in lakebed sediments in the CMR, their relative importance is unknown, and other unrecognized sources may exist.

Processes that sequester or release metals in lakebed sediments include sediment-water interface redox conditions (Davison 1993; Johnson 2008; Reiche et al. 2011) and sediment resuspension (Kalnejais et al. 2007; Terry 2011), but the degree to which these affect the availability of metals in the CMR is not known (Loder et al. 2016). Finally, stratigraphic variability in metal concentration in lakebed sediments can have significant consequences for bioavailability and may influence habitat management practices. Long Lake is older than most lakes in the CMR (White 2012) and is significantly older than wetland deposits; consequently, a paleolimnological approach allows a long-term assessment of metal sources.

Given the importance of aquatic habitats in the CMR for migratory birds, and the evidence of high levels of some toxic elements, we examined long-term patterns of metal deposition in lake sediments to evaluate whether this was a recent or historical pattern of contamination. Lake sediments are especially susceptible to heavy metal accumulation and typically have metal concentrations several orders of magnitude higher than those in overlying waters (Wersin et al. 1991), and thus, we expected that examining their levels through an archived chronosequence would shed light on metal history of this region. In this paper, we use bulk sediment geochemistry from a 10500 -year, $130 \mathrm{~cm}$ long paleolimnological record from Long Lake to examine metal sources, pathways, and abundance in lakebed sediments in the CMR.

\section{Metal sources}

Mineral occurrences in bedrock are common in the Nova Scotia-New Brunswick border region though surface outcrops are rare; most mineral deposits have been discovered through till, soil, and bog sediment sampling. Regional glaciation is responsible for the dispersal of metals in till. The region experienced five ice advance phases during the Wisconsinan glaciation $(75000-12000 \mathrm{cal} \mathrm{BP})$, 
and the dominant ice movement directions in the CMR were south and southeast (Stea et al. 1996). Consequently, till provenance was north of the Long Lake study site. The mineralogy of the till and associated soils is influenced by the Carboniferous sedimentary strata that underlie southeastern New Brunswick (Ryan and Boehner 1994). The Late Carboniferous Boss Point Formation contains sediment-hosted, strata-bound $\mathrm{Pb}-\mathrm{Zn}$-Cu deposits, particularly at Mt. Whatley and Hall's Hill, New Brunswick, both located 8 km from Long Lake (Fig. 1; New Brunswick Department of Natural Resources and Energy 2002). Minerals commonly found within the Boss Point Formation include pyrite $\left(\mathrm{FeS}_{2}\right)$, as well as local red bed deposits. The grey sandstone and red mudrocks of the Richibucto Formation are a significant source of strata-bound copper $(\mathrm{Cu})$ and zinc $(\mathrm{Zn})$ and also contain manganese $(\mathrm{Mn})$ oxides as well as chalcopyrite $\left(\mathrm{CuFeS}_{2}\right)$ and sphalerite $(\mathrm{ZnFeS})$. Mineralization in both these formations may be in part related to the steeply south-dipping regional faults. Chromium (Cr), titanium (Ti), and yttrium (Y) mineralization occurs within the Coverdale Anorthosite Complex (Hudgins 1999; Barr et al. 2007). Although the Coverdale Complex does not outcrop in the region, a significant paleo-placer deposit is located at Taylor Village, New Brunswick, $18 \mathrm{~km}$ north of Long Lake, which contains anomalous $\mathrm{Cr}, \mathrm{Ti}, \mathrm{Y}$, and many other trace elements indicating the Coverdale Complex as a probable source rock (Hudgins 1999; Barr et al. 2007).

Anthropogenic pollution of the CMR wetlands has likely been occurring for the past 150 years, mainly associated with industrialization in northeastern North America (Brännvall et al. 2001; Dunnington 2011). An increase in the metal content of lake sediments can result from both a global increase in atmospheric pollution and from the presence of local pollution sources in lake catchments. In the $\mathrm{CMR}$, archives of recent sediments suggest that atmospheric $\mathrm{Pb}$ deposition occurred during the 20th century as a result of industrial activity in Amherst and (or) leaded gasoline use (Sullyman 2003; Dunnington 2011).
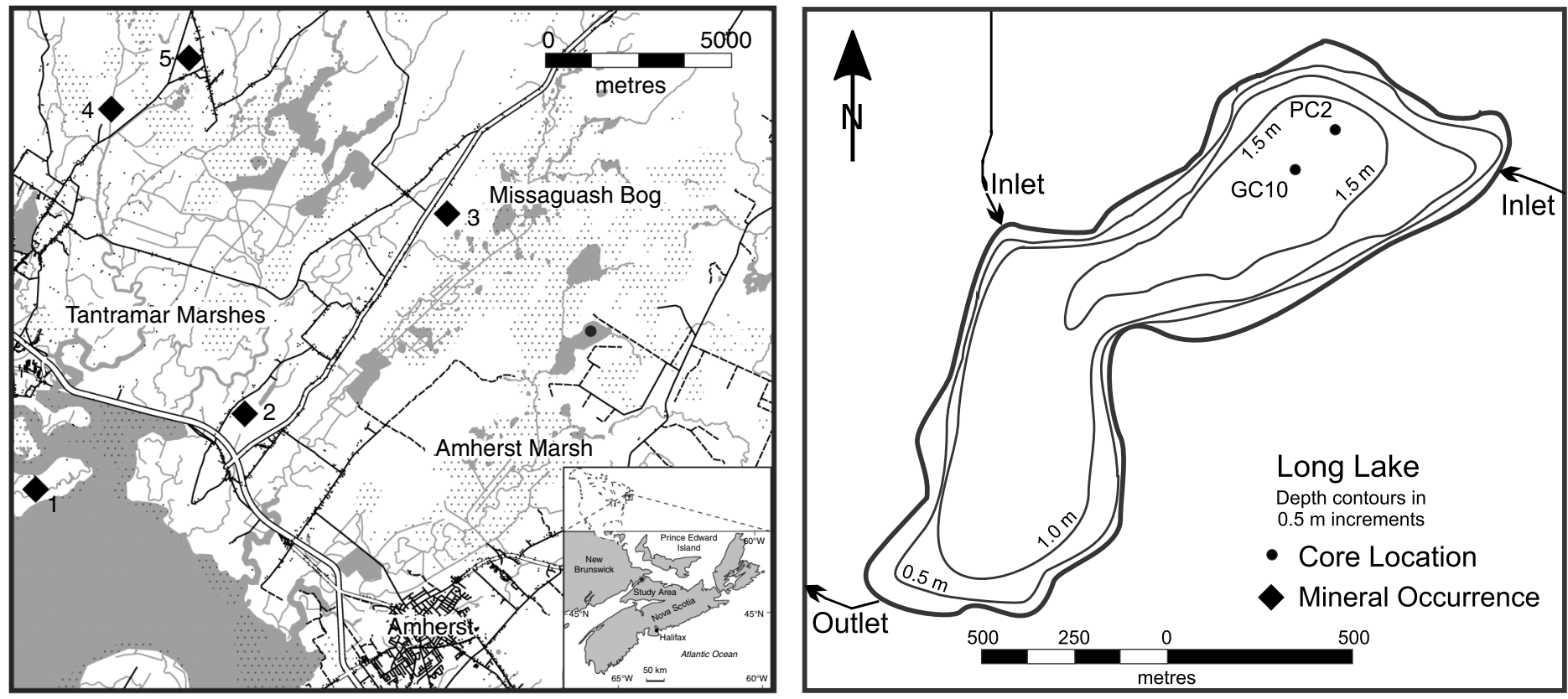

Fig. 1. Study site location. Long Lake is a shallow lake centrally located with the Cumberland Marsh Region, about $10 \mathrm{~km}$ inland from Chignecto Bay. Five local mineral deposits are located near Long Lake and include (1) British Settlement (Fe), (2) Mt. Whatley (Zn, Cu), (3) Hall's Hill (Zn, Cu), (4) Tantramar Copper $(\mathrm{Cu}, \mathrm{Au}, \mathrm{Pb}, \mathrm{Ag}, \mathrm{Zn})$, and (5) Midgic (Cu, Pb, $\mathrm{Zn}, \mathrm{Ag})$. Basemap data were obtained from the Natural Resources Canada CanVec data series. 


\section{Methods}

\section{Study site}

The CMR is large lowland at the head of the Bay of Fundy (Fig. 1). The region is known for strong winds, ample precipitation during the fall and spring seasons, and abundant precipitation during the winter (MacDonald and Clowater 2005). The landscape evolution of the CMR region during the Holocene has been influenced by eustatic sea level rise starting at $8 \mathrm{ka}$, an increase in tidal range, and subsidence of the Chignecto Isthmus (Shaw and Ceman 1999). Chalmers (1895) and Ganong (1903) suggested that the CMR was initially a large, shallow lake surrounded by peat bogs and till topographic highs that were later covered by salt marsh as relative sea level rose. The extensive wetlands in the CMR formed in the natural topographical depression inland from the coast (Chalmers 1895; Ganong 1903).

Long Lake is a small (93 ha), shallow (2.0 m maximum depth) lake located near the center of the CMR (Fig. 1). It was chosen for this study because of its central location within the CMR and its long aquatic sediment record (White 2012). Long Lake is fed by two unnamed creeks and drains to the south into Amherst Marsh, which ultimately drains into Chignecto Bay at the head of the Bay of Fundy. The southern end of the lake is surrounded by wetland, whereas till and glacial outwash sediment borders the northwest, north, and northeast shorelines of the lake. The till is underlain by Carboniferous sandstone, mudrock, and rare discontinuous limestone beds of the Balfron Formation (Ryan and Boehner 1994).

\section{Coring and water quality}

Lakebed sediments were obtained from Long Lake using a portable percussion coring system using PVC core tubes (Reasoner 1993) and a Glew gravity corer using lexan core tubes (Glew 1989; Glew et al. 2001). The gravity core was collected to provide undisturbed samples near the sediment-water interface, as percussion coring can disturb sediments (Reasoner 1993). Cores were collected from the deepest point of the lake at a depth of $1.9 \mathrm{~m}$ (Fig. 1; LL-PC2: 45 $55^{\prime} 33^{\prime \prime} \mathrm{N}$, $64^{\circ} 9^{\prime} 42^{\prime \prime} \mathrm{W}$; LL-GC10: $45^{\circ} 54^{\prime} 30^{\prime \prime} \mathrm{N}, 64^{\circ} 9^{\prime} 48^{\prime \prime} \mathrm{W}$ ). Both percussion (LL-PC2) and gravity (LL-GC10) cores were frozen, split, and subsampled at Acadia University. The percussion core was sectioned into $1.0 \mathrm{~m}$ lengths prior to transport; all cores were transported vertically prior to freezing. Subsamples $\left(1.0 \mathrm{~cm}^{3}\right)$ were obtained from the center of each core following splitting using a modified syringe. The percussion and gravity cores were collected in June and July 2011, respectively.

Water quality parameters of temperature, $\mathrm{pH}$, dissolved oxygen (DO), oxidation/reduction potential (ORP), and conductivity were measured at the coring location at the time of coring. Secchi depth was measured at the same site according to the method of Wetzel (1983).

\section{Age-depth model}

The chronology of the lake bottom sediment samples for the percussion core was constrained by five ${ }^{14} \mathrm{C}$ accelerator mass spectrometer (AMS) dates. Three samples were analyzed at the NSF-Arizona AMS facility, University of Arizona, and the other two samples were analyzed at the Lalonde AMS facility in Ottawa, Ontario. We used Bacon software with the IntCal13 ${ }^{14} \mathrm{C}$ calibration curve (Blaauw and Christen 2011; Reimer et al. 2013). The sediment chronology for the gravity core was loosely constrained by a prominent stratigraphic boundary that was observed in the percussion core but not in the gravity core, but further temporal constraint was not assessed. Our interpretation of these data reflects this uncertainty. 


\section{Bulk sediment geochemistry}

Our reconstruction of post-glacial environmental and metal concentration changes at Long Lake is predominantly based on sediment stratigraphy and bulk sediment geochemistry. Bulk geochemistry of lake sediment is a well-established technique for reconstructing historical metal sources from both natural and anthropogenic sources when there are insufficient monitoring data to provide this information (Dixit et al. 2000; Koinig et al. 2003; Gallagher et al. 2004; Tylmann et al. 2011; Dunnington et al. 2016). The geochemical parameters we assessed were carbon/ nitrogen $(\mathrm{C} / \mathrm{N})$ ratios, carbon stable isotopes $\left(\delta^{13} \mathrm{C}\right)$, nitrogen stable isotopes $\left(\delta^{15} \mathrm{~N}\right)$, and major/ trace element concentrations (As, chlorine $(\mathrm{Cl}), \mathrm{Cr}$, iron $(\mathrm{Fe}), \mathrm{Hg}, \mathrm{Mn}, \mathrm{Pb}$, sulphur $(\mathrm{S}), \mathrm{Ti}, \mathrm{Y}$, and $\mathrm{Zn}$ ). $\mathrm{C} / \mathrm{N}$ ratios and stable isotopes are commonly used in paleoenvironmental reconstructions (Meyers and Teranes 2001), and, in addition to the trace metals that were the focus of this study, $\mathrm{Ti}$ and $\mathrm{Cl}$ were measured as indicators of minerogenic content and possible marine influence, respectively (Engstrom and Wright 1984; Boyle 2000).

A modified $10 \mathrm{~cm}^{3}$ plastic syringe was used to extract $1 \mathrm{~cm}^{3}$ cylinders of sediment. Duplicates were taken as necessary to establish stratigraphic homogeneity and ensure enough sample mass for the analyses. Samples were dried in plastic boats at $60^{\circ} \mathrm{C}$ for $72 \mathrm{~h}$ in an open oven prior to sending samples for analysis. The elemental geochemistry of the sediment samples was measured by an Olympus $\mathrm{X}-50$ portable X-ray fluorescence (pXRF) spectrometer, following methods outlined by Rouillon and Taylor (2016), Loder et al. (2016), and Dunnington et al. (2016). XRF spectrometry is a method that is increasingly used to provide high-resolution elemental geochemistry in lake sediments (Koinig et al. 2003; Guyard et al. 2007; Brunschön et al. 2010; Kylander et al. 2011; Rydberg 2014; Dunnington et al. 2016; Gregory et al. 2017). Rouillon and Taylor (2016) demonstrated that pXRF was able to produce as good or better recoveries than ICP-AES for 9 of 11 elements assessed in the study (Ti, Cr, Mn, Fe, $\mathrm{Cu}, \mathrm{Zn}, \mathrm{Sr}, \mathrm{Cd}$, and $\mathrm{Pb}$ ). Non-detect values are reported in this study for $\mathrm{Pb}$ and $\mathrm{Cl}$, for which the manufacturer-provided detection limits were 2 and 33 ppm, respectively (Dunnington 2011).

$\mathrm{C} / \mathrm{N}$ ratios and stable isotopes $(\mathrm{C}, \mathrm{N})$ were measured at the Stable Isotopes in Nature Laboratory in Fredericton, New Brunswick, Canada; loss on ignition (LOI) and total $\mathrm{Hg}$ concentrations $\left(\mathrm{Hg}_{\text {total }}\right.$ ) were measured at Acadia University. $\mathrm{Hg}_{\text {total }}$ was determined using thermal decomposition and gold amalgamation atomic absorbance using a Nippon Instruments MA-2000. C/N and Hg data were not analyzed for core LL-GC10; this core was collected to provide an expanded characterization of recent sediments and was analyzed for elemental geochemistry and LOI.

For XRF and LOI analyses, selected samples were analyzed in triplicate to assess analytical precision, and internal standards (CAN174 and CAN277) used in previous studies were analyzed to ensure consistency with other XRF measurements (White 2012; Englehardt 2013; Misiuk 2014; Dunnington et al. 2016; Loder et al. 2016). Certified reference materials were not used for XRF measurements, and as such, XRF measurements should be treated as relative measures of element concentrations. For $\mathrm{Hg}_{\text {total }}$ analyses, all samples were analyzed in triplicate to assess precision, and the MESS-3 certified reference material was used to ensure accuracy. Samples analyzed by the Stable Isotopes in Nature Laboratory included duplicate samples and an internal quality assurance/quality control protocol. Error bars are included in our figures and represent one standard deviation, and all means are presented $\pm \mathrm{SD}$ in the text.

\section{Results}

\section{Limnology}

Long Lake is circumneutral in its $\mathrm{pH}$ ( $\mathrm{pH} 7.28$; Table 1 ). Due to its shallow depth and exposure to wind (30-60 cm waves observed during sampling), it is likely that the lake does not stratify and is 
Table 1. Water quality parameters for Long Lake (June 2011).

\begin{tabular}{ll} 
Parameter & Value \\
\hline Temperature & $24.4^{\circ} \mathrm{C}$ \\
$\mathrm{pH}$ & 7.28 \\
\hline ORP & $145.3 \mathrm{mV}$ \\
\hline Dissolved oxygen & $9.84 \mathrm{mg} / \mathrm{L}$ \\
\hline Conductivity & $40 \mu \mathrm{S} / \mathrm{cm}$ \\
\hline Secchi depth & $0.72 \mathrm{~m}$ \\
\hline
\end{tabular}

Note: ORP, oxidation/reduction potential.

saturated during the open water season. The average measured conductivity was $40 \mu \mathrm{S} / \mathrm{cm}$. The secchi depth was $0.72 \mathrm{~m}$ due to high concentrations of dissolved organic matter and re-suspended sediment in the water column.

\section{Age-depth model}

Five radiocarbon dates were obtained for Long Lake (Table 2, Fig. 2). An age-depth model based on the weighted-mean most-probable age was calculated using Bacon software (Blaauw and Christen 2011). Based on this age-depth model, Long Lake became a freshwater lacustrine environment before $10313 \mathrm{cal} \mathrm{BP}$, which is consistent with deglaciation and falling relative sea level at the Chignecto Isthmus (Shaw et al. 2002). An erosive surface was found at $8 \mathrm{~cm}$ depth, likely as a result of anthropogenic lake level lowering and wave scour ca. AD 1860 (Dunnington 2011). This erosive surface was not visible in the gravity core, indicating that the sediment captured by the gravity core was likely deposited after AD 1860. Geochemical and sedimentological similarity between sediment in the gravity core and sediment at the top of the percussion core confirmed this interpretation. Because of this geochemical and sedimentological similarity we have assigned sediments from the top of LL-PC2 and LL-GC10 to the same stratigraphic unit, although there are insufficient data to infer the degree to which the cores overlap stratigraphically.

Table 2. Long Lake radiocarbon ages for the Long Lake percussion core.

\begin{tabular}{|c|c|c|c|c|c|c|}
\hline Lab sample number & Depth $(\mathrm{cm})$ & Material & $\delta^{13} \mathrm{C}$ & Age $\left({ }^{14} \mathrm{C}\right.$ year $\left.\mathrm{BP}\right)$ & $\begin{array}{c}\text { Calendar } \\
\text { age (cal BP) }\end{array}$ & $\begin{array}{l}\text { Calendar range } \\
(2 \sigma)(\text { cal BP) }\end{array}$ \\
\hline LL082011-C2-39 & 94 & Wood fragment & -29.4 & $9148 \pm 49$ & 10313 & $10225-10431$ \\
\hline UOC-0844 & 70.5 & Wood & NA & $8582 \pm 28$ & 9501 & $9568-9531$ \\
\hline LL082011-C2-87 & 46 & Wood fragment & -27.0 & $4396 \pm 55$ & 4981 & $4850-5278$ \\
\hline UOC-0845 & 37.5 & Plant & NA & $575 \pm 18$ & 607 & $537-562$ \\
\hline LL082011-C2-124 & 9 & Twig fragment & -26.7 & $623 \pm 34$ & 601 & $550-660$ \\
\hline
\end{tabular}

Note: Samples were analyzed at the University of Arizona AMS Laboratory in Tuscon, Arizona (LL), USA, and at the Lalonde AMS Laboratory, Ottawa, Ontario (UOC), Canada. Radiocarbon ages were calibrated using the Intcal13 dataset and are given as calendar years before present (Reimer et al. 2013). Calendar age reported as median probability age as calculated by CALIB 7.0.4 (Stuiver and Reimer 1993). 

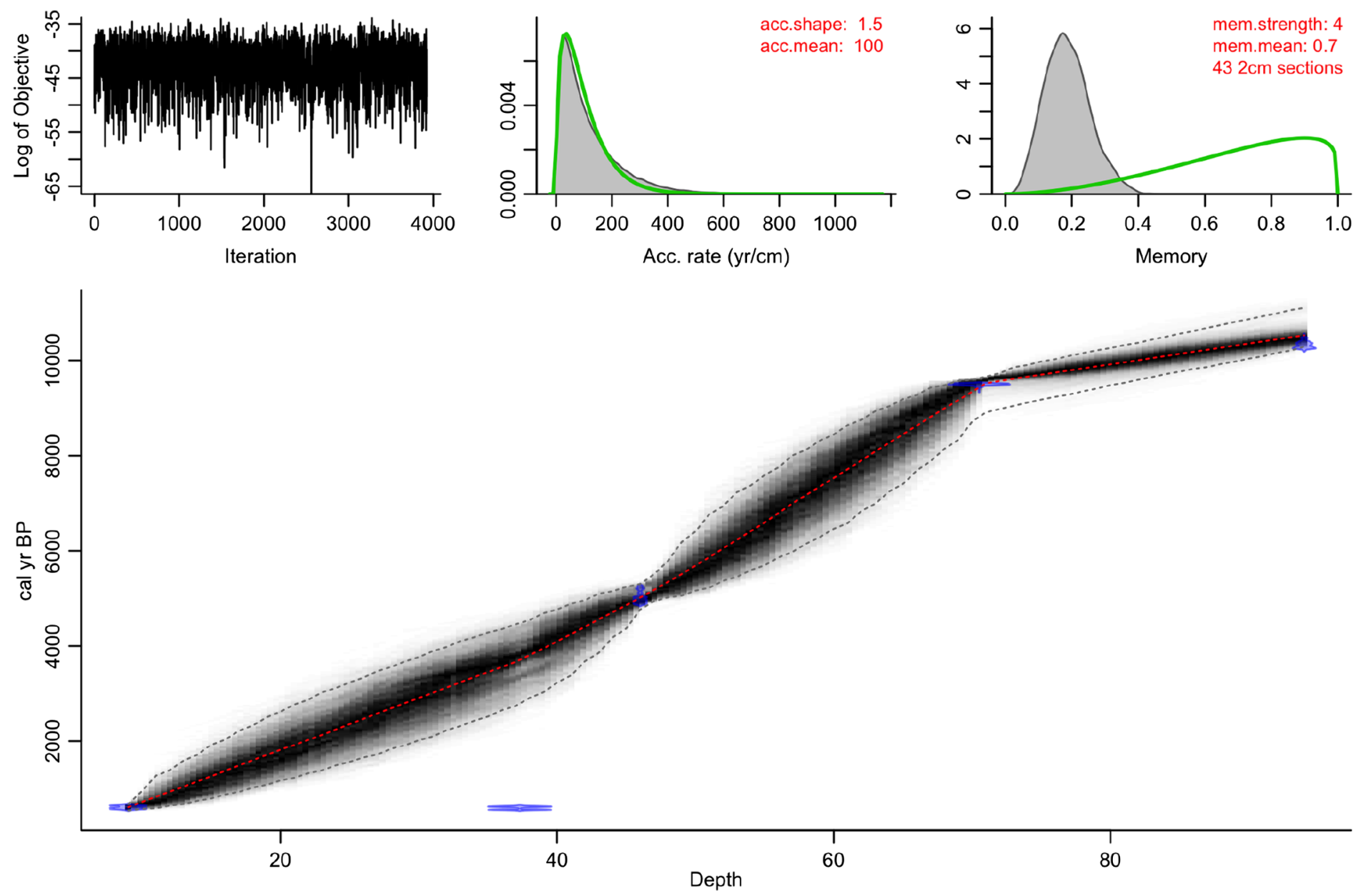

Fig. 2. Age-depth model for the Long Lake percussion core (LL-PC2). The chronology was established by a weighted probability mean calculated using Bacon software (Blaauw and Christen 2011). A lack of systematic change in the log of objective (top left) indicates a stable solution among Markov chain Monte Carlo (MCMC) iterations (Blaauw and Christen 2011).

\section{Bulk sediment geochemistry}

Unit I (percussion core: bottom of core-105 cm; >10 $313 \mathrm{cal} \mathrm{BP)}$

Unit 1 was a poorly sorted, red-brown sand that also contained silt and clay (Fig. 3). Unit 1 was characterized by low organic content $(<1 \%)$ and higher concentrations of minerogenic elements (potassium $(\mathrm{K})$, rubidium $(\mathrm{Rb}), \mathrm{Ti}$, and zirconium $(\mathrm{Zr})$ ) than Unit 2. In Unit $1, \mathrm{~Pb}$ was above the detection limit but had low concentration $(<4.8 \mathrm{ppm}) . \delta^{15} \mathrm{~N}$ values were higher in Unit $1(3.00 \% \mathrm{t}$ $0.25 \% ; n=3)$ than in Unit $2(1.12 \%$ o $\pm 1.36 \%$; $n=11)$, and $\mathrm{C} / \mathrm{N}$ values were low $(<7.0)$. Unit 1 contained low concentrations of As ( $<8 \mathrm{ppm}), \mathrm{Cr}(<32 \mathrm{ppm})$, and $\mathrm{Hg}(<2 \mathrm{ppb})$.

Low $\mathrm{C} / \mathrm{N}$ values $(<10)$ suggest an aquatic influence, though $\mathrm{Cl}<1000 \mathrm{ppm}$ was consistent with freshwater systems and did not support sustained saltwater influence (Branchu and Bergonzini 2004). Hg and $\mathrm{Pb}$ concentrations through this zone were asynchronous and appeared to correlate well with organic and clastic contents, respectively. Both LOI and Hg were very low, which is to be expected as available $\mathrm{Hg}$ readily complexes with organic material (O’Driscoll et al. 2011). 


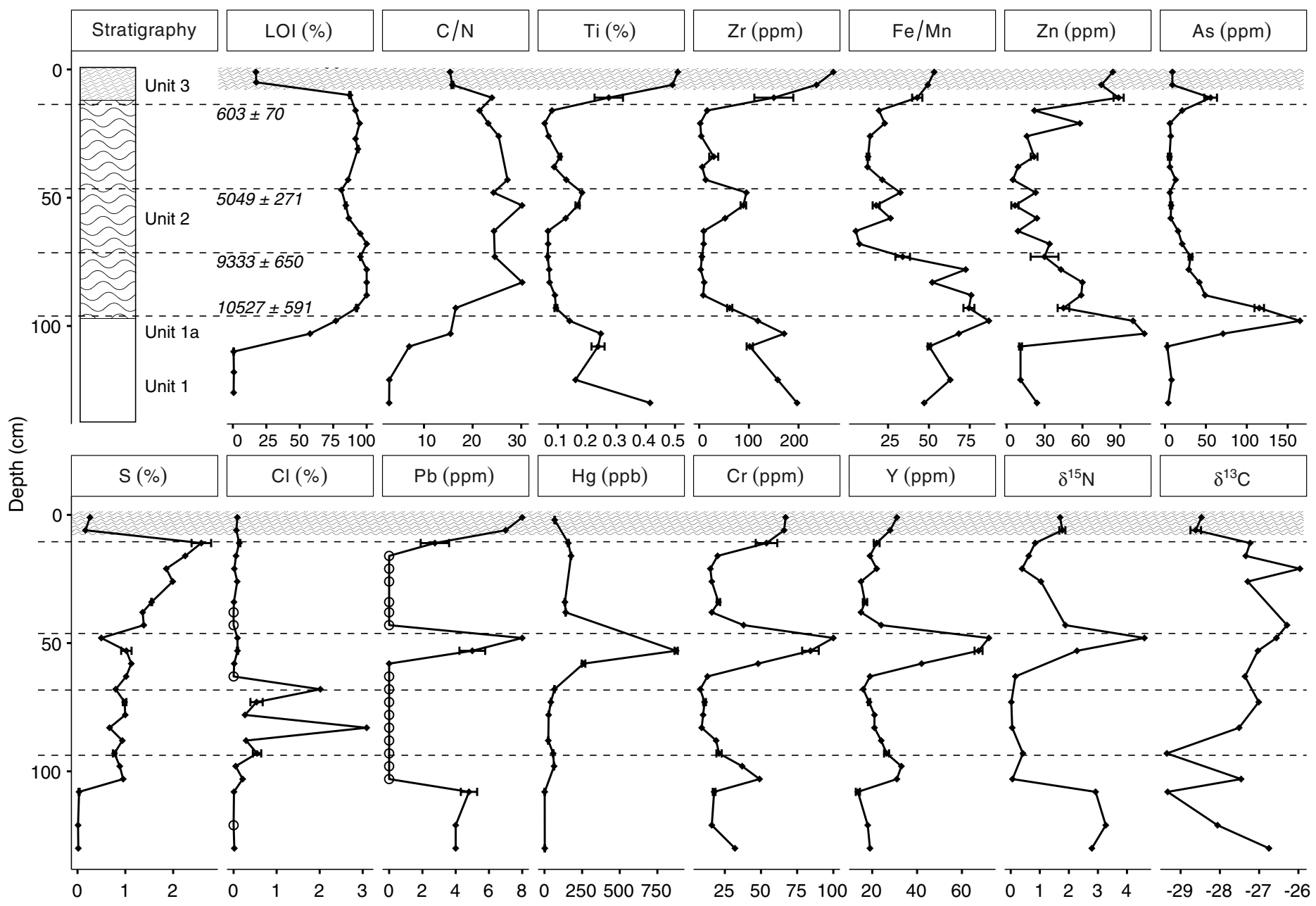

Fig. 3. Long Lake percussion core (LL-PC2) sediment stratigraphy and selected proxy analyses. Open circles indicate that values were below the detection limit. LOI, loss on ignition.

Unit la (percussion core: $105-95 \mathrm{~cm} ;>10313 \mathrm{cal} \mathrm{BP}$ )

Unit 1a could be distinguished from Unit 1 based on a slight colour change, increasing LOI values, $\mathrm{C} / \mathrm{N}$ values increasing to between 10 and 20 , and $\mathrm{Pb}$ and $\mathrm{Hg}$ values that reflected lower minerogenic content. Arsenic levels (>150 ppm) were the highest in the core. This unit likely represented a period of increased watershed productivity and the establishment of a freshwater lake environment, as indicated by the significant increase in organic content (LOI values) and overall decrease in Ti indicating decreasing shoreline erosion. The $\mathrm{C} / \mathrm{N}$ values (between 10 and 20) indicated that both terrestrial and aquatic carbon sources contributed to lake sedimentation (Meyers and Teranes 2001); however, the $\mathrm{C} / \mathrm{N}$ vs. $\delta^{13} \mathrm{C}$ biplot (Fig. 4) indicated that the aquatic carbon likely had a strong freshwater affinity (Mackie et al. 2007). The $\mathrm{Cl}$ concentrations were low and indicated that saltwater egress did not occur during this interval (Branchu and Bergonzini 2004).

Bulk geochemical data from Unit 1 suggested a period of low productivity and significant clastic sediment input. The coarse-grained sand- to gravel-sized sediment in this zone was similar to sediment exposed along the shoreline of the lake. This is believed to be glacio-marine till that may have been modified by wave action (Rampton 1984). 


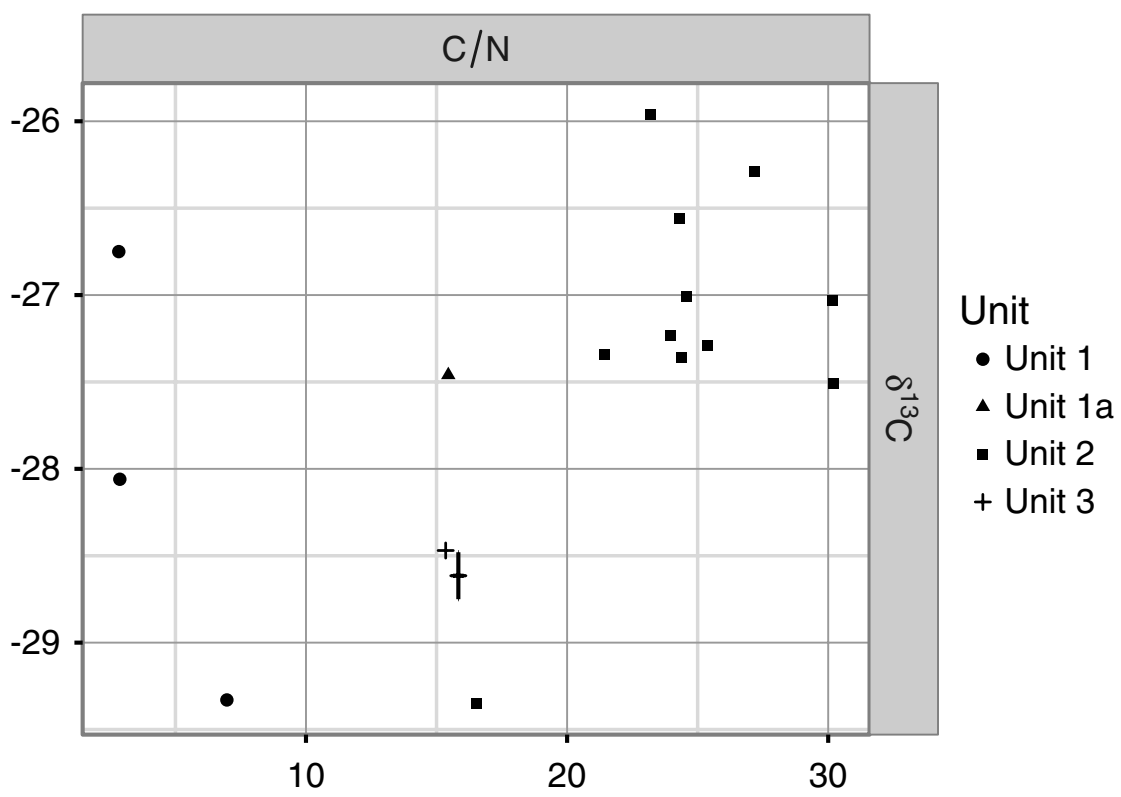

Fig. 4. Carbon $(\mathrm{C})$, nitrogen $(\mathrm{N})$, and stable isotope $\left(\delta^{13} \mathrm{C}\right)$ signatures of organic matter from the Long Lake perucussion core (LL-PC2).

Unit 2 (percussion core: $105-8 \mathrm{~cm} ;>10313-60 \mid$ cal BP)

Unit 2 was a dark brown to black gyttja. Organic content increased rapidly at the base of Unit 2 and remained high throughout Unit $2(92.5 \% \pm 6.0 \% ; n=16)$. This gradational boundary between Unit 1 and Unit 2 was also evident in the $\mathrm{C} / \mathrm{N}$ ratios and minerogenic elements $(\mathrm{K}, \mathrm{Rb}, \mathrm{Ti}$, and $\mathrm{Zr}$ ) and took place over a depth range of $\sim 20 \mathrm{~cm}$. Two peaks of $\mathrm{Cl}$ existed at depths of $83 \mathrm{~cm}$ $(3.10 \% ; 9220 \mathrm{cal} \mathrm{BP})$ and $68 \mathrm{~cm}(2.02 \% ; 7560 \mathrm{cal} \mathrm{BP})$ over a background concentration of $0.25 \%$. In Unit $2, \mathrm{C} / \mathrm{N}$ values were greater than 20 , indicating predominantly sustained allochthonous, terrestrial organic input (Meyers and Teranes 2001). The $\mathrm{C} / \mathrm{N}$ vs. $\delta^{13} \mathrm{C}$ biplot also supported this interpretation, with values plotting within the C3 plant range (Meyers and Lallier-Vergés 1999; Mackie et al. 2007).

This unit had a wood-rich section $(50-24 \mathrm{~cm})$ that began at approximately $5560 \mathrm{cal} \mathrm{BP}$. This wood-rich section coincided with peaks of barium (Ba; $2498 \mathrm{ppm}), \mathrm{Cr}(106 \mathrm{ppm}), \delta^{15} \mathrm{~N}(4.6 \%)$, $\mathrm{Pb}(8 \mathrm{ppm})$, vanadium (V; $233 \mathrm{ppm}), \mathrm{Y}(72 \mathrm{ppm})$, and $\mathrm{Hg}$ (875 ppb). Peaks were between $2.2(\mathrm{~V})$ and $18.6(\mathrm{Hg})$ times above pre-peak Unit 2 concentrations. An increase in minerogenic elements ( $\mathrm{K}$ 2.6; Rb 1.1; Ti 2.2; and Zr 3.4 times above background levels) and a decrease in organic content (pre-peak average $94.8 \%$; minimum $81 \%$ ) were also observed during this period. The increased prevalence of $\mathrm{Zr}$ with respect to $\mathrm{Rb}$ suggested a coarse-grained clastic influx (Dypvik and Harris 2001; Kylander et al. 2011). Maximum anomalies all occurred between 47 and $53 \mathrm{~cm}$ depth (5220-5890 cal BP).

The environment represented by Unit 2 was a period of increased allochthonous productivity and rapid organic sedimentation. The average LOI value for this zone was $92.5 \%$, and minerogenic element concentrations were low throughout this zone; however, there were two high $\mathrm{Cl}$ values ca. 8000 cal BP. The $\mathrm{C} / \mathrm{N}$ vs. $\delta^{13} \mathrm{C}$ biplot data (Fig. 4) did not suggest that the $\mathrm{Cl}$ spikes represented an environment of prolonged saltwater inundation. 


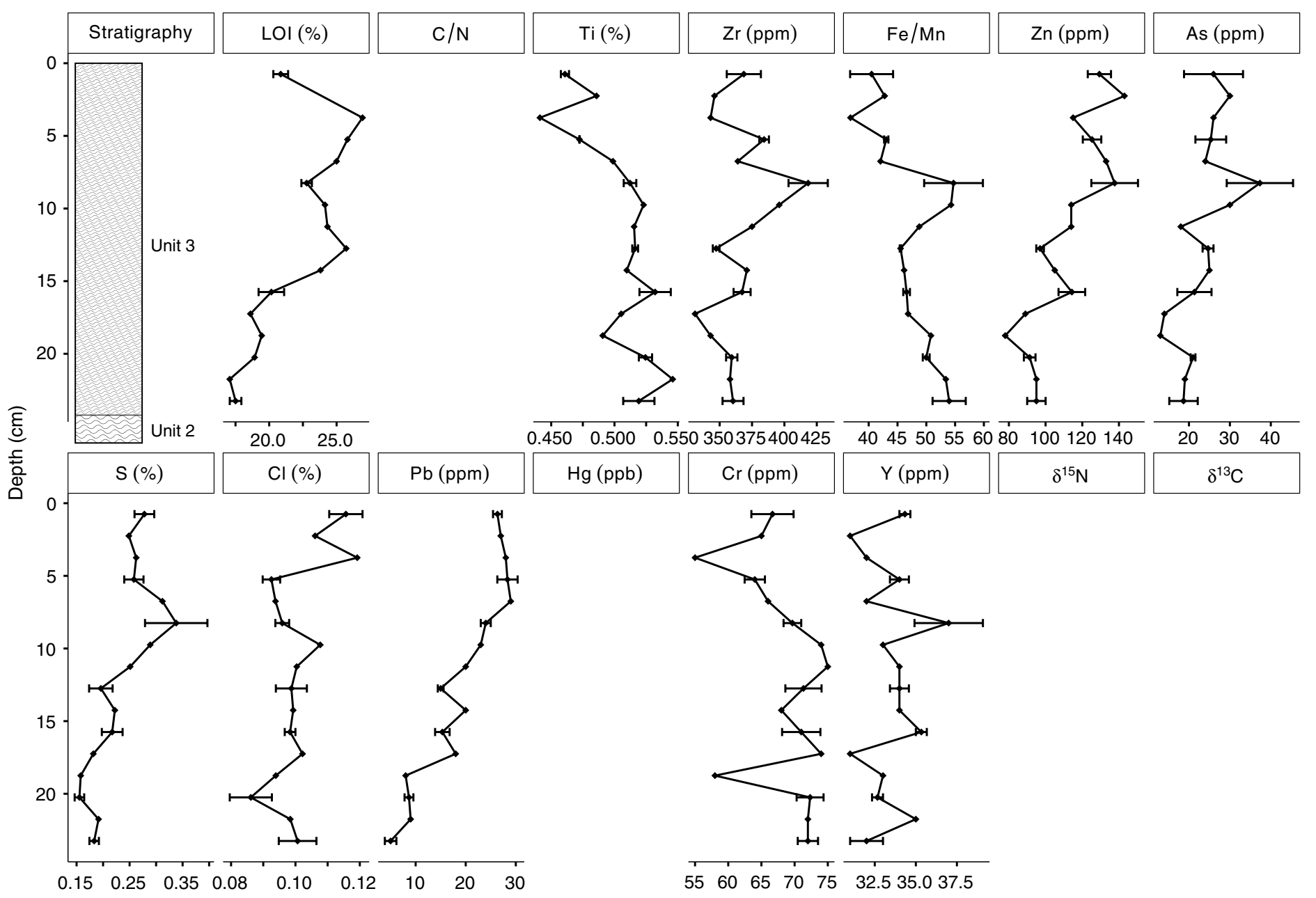

Fig. 5. Long Lake gravity core (LL-GC10) sediment stratigraphy and selected proxy analyses. Unit 2 was not visible in LL-GC10; however, it is shown in the schematic to illustrate its relationship with Unit 3. Note the difference of scales between Figs. 3 and $5 . \mathrm{C} / \mathrm{N}, \mathrm{Hg}, \delta^{15} \mathrm{~N}$, and $\delta^{13} \mathrm{C}$ were not measured in the gravity core sediments. LOI, loss on ignition.

Unit 3 (percussion core: $8 \mathrm{~cm}$ - top of core; gravity core: $24 \mathrm{~cm}$-top of core; AD 1860-present)

Unit 3 was a dark brown, organic-rich clay. LOI in this unit increased up-core from $17 \%$ to $27 \%$. An erosive surface was found between Unit 2 and Unit 3 (Figs. 3, 5), likely as a result of humaninduced lake level lowering and wave scour ca. AD 1860 (Dunnington 2011). Unit 3 exhibited litthe variability and was defined by elevated concentrations of minerogenic elements ( $\mathrm{K}>1.3 \%$; $\mathrm{Rb}>87 \mathrm{ppm}$; $\mathrm{Ti}>0.44 \%$; and $\mathrm{Zr}>236 \mathrm{ppm}$ ) and elevated concentrations of $\mathrm{Zn}, \mathrm{Cr}, \mathrm{Pb}$, and cobalt (Co) (mean Zn $107 \pm 21$ ppm; Cr $68 \pm 5.4$ ppm; Pb $18 \pm 8.4$ ppm; Co $13 \pm 1.6$ ppm; $n=18$ ). Elevated As concentrations were not associated with Unit 3; however, a peak in As (56 ppm) occurred just below the contact between Unit 2 and Unit $3 . S$ and calcium (Ca) concentrations were significantly reduced ( $\alpha=0.01$ ) in Unit 3 (mean S $0.235 \% \pm 0.054 \%$ and $\mathrm{Ca} 0.534 \%$ $\pm 0.050 \%$ ) compared with Unit 2 (S $0.497 \% \pm 0.59 \%$; Ca $3.40 \% \pm 0.98 \%$; both $t_{16} \geq 7.3$, $p<0.0001)$. 
Table 3. Interim sediment quality guidelines (ISQGs), probable effect levels (PELs), and peak concentrations found in the Long Lake sediments for selected elements.

\begin{tabular}{lcccc} 
Element & ISQG $(\mathrm{ppm})$ & PEL $(\mathrm{ppm})$ & Surficial concentrations $(\mathrm{ppm})$ & Peak concentrations (ppm) \\
$\mathrm{As}$ & 5.9 & 17.0 & $26^{*}$ & $165^{*}$ \\
$\mathrm{Cu}$ & 35.7 & 197 & 17 & 24 \\
$\mathrm{Hg}$ & 0.17 & 0.486 & 0.067 & $0.875^{\star}$ \\
$\mathrm{Pb}$ & 35.0 & 91.3 & 26 & 29 \\
$\mathrm{Zn}$ & 123 & 315 & 129 & 143 \\
\hline
\end{tabular}

Note: Asterisk $\left({ }^{*}\right)$ denotes that concentrations exceed the PEL. Italics indicate measurements from our study that were obtained using X-ray fluorescence, which may not be directly comparable with CCME (1999) guidelines.

\section{Discussion}

\section{Metal sources and deposition through time}

Applying a paleolimnological approach at Long Lake resulted in a 10500 year record of metal deposition in lakebed sediments and indicated that lakebed sediment concentrations of $\mathrm{Hg}$ fluctuated substantially, and in some sections of the core exceeded the interim sediment probable effects level (PEL) established by the CCME (1999) (Table 3). XRF measurements reported Zn concentrations that were above the interim sediment quality guidelines (ISQG) and As concentrations that were above the PEL; however, the degree to which XRF measurements from this study are consistent with the values reported by the CCME (1999) is unknown. The bulk geochemical data were effective in identifying that significant natural and anthropogenic environmental changes have occurred and have influenced both sediment composition and metal deposition.

Lead values were highest in Unit $1(\sim 4 \mathrm{ppm})$ and Unit $3(\sim 20 \mathrm{ppm})$, both of which were likely minerogenic and were derived, in part, from till deposits that have a northwest provenance (Stea 1982; Foisy and Prichonnet 1991; Shaw et al. 2002). The strataform Pb-Zn deposits in the underlying Boss Point Formation (New Brunswick Department of Natural Resources and Energy 2002) are the likely source based on paleo-iceflow direction and the coincident elevated levels of $\mathrm{Pb}, \mathrm{Zn}$, and $\mathrm{Ti}$ in Unit 3 and Unit 1. Although lead shot is considered a significant source of bioavailable lead in the wetlands of Atlantic Canada (Stevenson et al. 2005), in this study, evidence of its impact in our bulk geochemical analysis of lakebed sediments in the CMR was not observed. Although the CMR was subjected to significant waterfowl hunting pressure throughout the 19th and 20th centuries (Schwab and Daury 1989), lead shot was banned in 1999 and the water chemistry at Long Lake ( $\mathrm{pH} \sim 7.0$ ) is not conducive to lead mobility (Outridge and Wang 2015). Other paleolimnological studies in Nova Scotia noted significantly higher $\mathrm{Pb}$ concentrations in lakebed sediments, associated primarily with local industrial and residential development (Terry 2011; Misiuk 2014).

Arsenic and $\mathrm{Cr}$ were variable but had elevated concentrations in the Long Lake sediments. The vertical distributions of As and $\mathrm{Cr}$ concentrations in the Long Lake sediments were likely affected by changes to the redox environment in the sediment or water column, as high sedimentary As and $\mathrm{Cr}$ concentrations have been reported at the onset of anoxia in some lakes (Schaller et al. 1997). Multiple sources for these metals are likely and include minerogenic material, groundwater, and atmospheric deposition. The Taylor Village paleo-placer deposit, located $18 \mathrm{~km}$ from Long Lake, contains anomalous $\mathrm{Cr}, \mathrm{Ti}$, and $\mathrm{Y}$; the bedrock source for the mineralization is likely the Coverdale Anorthosite Complex (Hudgins 1999; Barr et al. 2007). It is likely that these elements were 
transported to the Long Lake watershed in till. The copper and sulphur form organic (chelate) complexes (Fraser 1961) and the source bedrock are thought to be the underlying Boss Point Formation. The pathway for these minerals may have been metal-rich groundwater ascending major permeable structures such as the nearby Dorchester Fault. The source of the metals may be the underlying sandstone, but this has not been demonstrated.

Arsenic and $\mathrm{Zn}$ concentrations were particularly high in Unit 1a (As $>150 \mathrm{ppm}$ and $\mathrm{Zn}>90 \mathrm{ppm}$ ). Similar to $\mathrm{Cr}$, the vertical distribution of $\mathrm{Zn}$ concentrations in the Long Lake sediments was likely also affected by changes to sediment or water column chemistry (Outridge and Wang 2015). The primary source was likely the mineral arsenopyrite $\left(\mathrm{AsFeS}_{2}\right)$ found in regional soils and till derived from a wide variety of bedrock types in both Nova Scotia and New Brunswick, and $\mathrm{Pb}-\mathrm{Zn}$ deposits that were also a likely source of $\mathrm{Pb}$ to the Long Lake sediments (New Brunswick Department of Natural Resources and Energy 2002). Craw et al. (2003) showed that arsenopyrite is soluble in oxidizing conditions while being insoluble or stable in moderately reducing environments, suggesting that redox changes at the sediment-water interface may concentrate As in sediments that experience sudden changes in redox state (Masscheleyn et al. 1991; Schaller et al. 1997). Sources for As and Zn into Long Lake include the erosion and weathering of As- and Zn-bearing sediment, with elevated values at the top of Unit 1a and base of Unit 3 being a result of post-depositional mobility.

Increases in $\mathrm{Pb}, \mathrm{Hg}$, and $\delta^{15} \mathrm{~N}$ in the core at $5500 \mathrm{cal} \mathrm{BP}$ (Fig. 3) were likely the consequence of regional fires and indicated that a significant reservoir of these metals exists in the natural environment. Increases in $\mathrm{Hg}$ have been observed following wildfires and associated storm runoff (Garcia and Carignan 1999; Caldwell et al. 2000), in addition to increases in $\delta^{15} \mathrm{~N}$ (Spencer et al. 2003). The fire events were broadly coincident with a period of warming that may have also been a period of low precipitation in Atlantic Canada (Mott et al. 2009; Spooner et al. 2014). Wetter conditions and a raised water table at the site have persisted since $4000 \mathrm{cal} \mathrm{BP}$, likely as a result of changing climate conditions and rapid salt marsh aggradation in response to sea level rise (Shaw and Ceman 1999). Unlike other metals that peaked at this time, the concentrations of $\mathrm{Hg}$ following the event were elevated by a factor of 2 compared with concentrations prior to the event, suggesting the potential for $\mathrm{Hg}$ to remain elevated following its introduction to a system (Rydberg et al. 2015).

Peak concentrations of As, $\mathrm{Hg}$, and $\mathrm{Zn}$ all exceeded Canadian ISQG guidelines, and, in the case of As and Hg, exceeded the probable effects level as established by the CCME (1999) (Table 3). Peak concentrations of As, $\mathrm{Hg}$, and $\mathrm{Zn}$ all occurred prior to European settlement of North America, suggesting the potential for guideline-exceeding concentrations of these elements to occur due to natural phenomena. Surficial concentrations of As and Zn also exceeded ISQG guidelines, likely as a result of increased erosion from human-induced water level change and atmospheric deposition.

\section{Metal pathways through time}

\section{Pathway I: shoreline erosion}

Periods of high metal concentrations (As, $\mathrm{Pb}, \mathrm{Zn}, \mathrm{Cr}$ ) generally coincided with high concentrations of minerogenic elements $(\mathrm{K}, \mathrm{Rb}, \mathrm{Ti}$, and $\mathrm{Zr})$, suggesting that clastic input is a major factor controlling the transport of these metals to lakebed sediments. Local sources of mineralized $\mathrm{Pb}$, $\mathrm{Zn}$, and As exist as original bedrock sources for elevated concentrations found in till deposits, which were deposited directly or were dissolved and re-precipitated into the Long Lake sediments. The deposition of Unit 3 (AD 1860-present) and the elevated concentrations of minerogenic elements are likely related to sustained catchment erosion following 1860. Construction of the Ship Railway, construction and renovation of cottages, and road construction all contributed minerogenic sediment to the lake over the past 200 years; a process that has been demonstrated in other lakes (Garrison and Wakeman 2000; Dunnington et al. 2016). In addition, a raised lake level 
associated with construction of an outlet dam and the Amherst Marsh impoundment by DUC in the 1980s would have increased both erosion around the edge of the lake and minerogenic sediment influx.

\section{Pathway 2: large-scale fire event}

$\mathrm{Pb}$ and $\mathrm{Hg}$ concentrations were generally both low throughout Unit 2, but isolated high $\mathrm{Hg}$ and $\mathrm{Pb}$ values occurred at $\sim 5000 \mathrm{cal} \mathrm{BP}$. During this time an abrupt hydroclimatic transition took place (Jetté and Mott 1995; Forster et al. 2006; Booth et al. 2012) as regional climate became much drier and there was likely an increased incidence of forest fires (Railton 1975; Ali et al. 2009). Forest fires commonly result in the significant mobilization of cations concentrated in forest biomass, which are then transported to lakes by surface and groundwater runoff (Young and Jan 1977; Caldwell et al. 2000). This process could increase both nutrient and metal deposition into the lake basin (Kelly et al. 2006). $\mathrm{Pb}$ concentrations appeared to be associated with clastic input at this time, although other metals $(\mathrm{Hg}$, $\mathrm{Cr}, \mathrm{Y}$ ) that were not generally associated with clastic input (Ti) were also elevated to the same magnitude. This suggests that fire as a pathway does not just enable an increase in clastic delivery to the lake basin, but also produces a unique set of metals through both ash and clastic deposition.

\section{Pathway 3: atmospheric deposition}

Both Unit 1 and Unit 3 contained elevated $\mathrm{Pb}$ concentrations in comparison with Unit 2, however concentrations in Unit 3 were 2-3 times higher than in Unit 1. Higher Pb concentrations in Unit 3 were likely a result of the contribution of atmospheric deposition after 1900, associated with fossil fuel combustion, as has been observed in other cores in the area (Sullyman 2003; Dunnington 2011).

\section{Potential for sequestration and release}

Surficial concentrations of metals in the Long Lake sediments were low, but much higher concentrations were found deeper in the core (i.e., from older dates). Elevated concentrations of As, $\mathrm{Zn}, \mathrm{Hg}, \mathrm{Y}$, and $\mathrm{Cr}$ all were found at a depth of $50 \mathrm{~cm}$, and it is unlikely that this horizon is unique to Long Lake. Natural resuspension at this depth is unlikely, but the engineering of wetlands in the Amherst Marsh is ongoing (Dunnington 2011), and future resuspension due to human activities is likely. Suspending particles with elevated metal concentrations has the potential to increase the bioavailability of these metals, and should be avoided in the CMR given our results. Similarly, higher concentrations of metals in till surrounding Long Lake have the potential to be liberated with development or water level changes that may increase shoreline erosion (Kalnejais et al. 2007).

Elevated concentrations of As and Zn were found at both transitions (Unit 1 to Unit 2; Unit 2 to Unit 3), suggesting that their deposition may have been related to environmental changes that occurred at these times. The solubility of As and $\mathrm{Zn}$ are affected by changes in redox chemistry at the sediment-water interface, particularly a decrease in effective solubility in oxidizing conditions, as As in particular is enriched in sediment by Fe and Mn precipitation (Masscheleyn et al. 1991; Schaller et al. 1997). When oxidizing conditions are present, more of these metals are removed from the water column and sequestered in sediments. Conversely, when reducing conditions are present, there is a potential for metals sequestered in sediment to be released (Aggett and O'Brien 1985). The CMR is a shallow-water system, and large changes in redox are unlikely but possible in the case of algal blooms or encroachment of bog, both of which promote reducing conditions (Cohen 2003).

$\mathrm{Hg}$ values in Unit 2 were elevated compared with the values measured in Unit 1, which is consistent with the process of available $\mathrm{Hg}$ readily complexing with organic matter (Lepane et al. 2007; O'Driscoll et al. 2011). However, the greatest concentration of $\mathrm{Hg}$ occurred during the peak of other metals ca. $5000 \mathrm{cal} \mathrm{BP}$, coincident with a time of high clastic input to Long Lake. It is, therefore, likely 
that the sequestration of $\mathrm{Hg}$ in the Long Lake sediments was a result of increased supply to the water column with constant removal rates from the water column due to complexing with available organic matter.

\section{Conclusions}

In this paper, we used bulk sediment geochemistry from a 10500 -year, $130 \mathrm{~cm}$ long paleolimnological record from Long Lake, CMR, to examine metal sources, pathways, and abundance in lakebed sediments in the CMR. Sources for metals in the CMR included bedrock minerogenic deposits, which were deposited in Long Lake through groundwater transport, shoreline erosion, and atmospheric deposition. The geochemical data suggest that a large-scale fire event enriched concentrations of As, $\mathrm{Zn}, \mathrm{Hg}, \mathrm{Y}$, and $\mathrm{Cr}$ ca. 5000 cal BP through clastic sediment delivery and atmospheric deposition. Arsenic and Zn were concentrated in the sediment by sudden redox changes at the sediment-water interface. Peak concentrations of As, $\mathrm{Hg}$, and $\mathrm{Zn}$ all occurred prior to European settlement of North America, suggesting that small lakes and wetlands may sequester toxic elements at concentrations that exceed Canadian guidelines for the protection of aquatic life, and that this process may occur through natural phenomena (e.g., fire, erosion, organic complexation). Anthropogenic change in the CMR is ongoing, and practices that induce sudden redox changes, re-suspend sediments, or induce further shoreline erosion, such as wetland construction and restoration, have the potential to increase the bioavailability of metals sequestered in CMR sediments.

\section{Acknowledgements}

This study was funded by NSERC, Ducks Unlimited Canada, Irving Oil, and Acadia University. Special thanks to the staff at Ducks Unlimited Canada Amherst office for logistical support and accommodations through the Beaubassin Research Centre. The Beaubassin Research Centre, located in Aulac, New Brunswick, is a partnership between Acadia University, Irving Oil Ltd., and Ducks Unlimited Canada, and is used extensively for ecological research. We thank the referees for helpful and insightful comments on an earlier version of this manuscript.

\section{Author contributions}

Conceived and designed the study: DWD, HW, ISS. Performed the experiments/collected the data: DWD, HW, ISS. Analyzed and interpreted the data: DWD, HW, ISS. Contributed resources: ISS, CW, NJO, NRM. Drafted or revised the manuscript: DWD, HW, ISS, MLM, NJO.

\section{Competing interests}

MLM and NJO are currently serving as Subject Editors for FACETS, but were not involved in review or editorial decisions regarding this manuscript.

\section{Data accessibility statement}

All relevant data are within the paper.

\section{References}

Adler FEW. 1944. Chemical analyses of organs from lead-poisoned Canada geese. Journal of Wildlife Management, 8: 83-85. doi:10.2307/3796202.

Aggett J, and O'Brien GA. 1985. Detailed model for the mobility of arsenic in lacustrine sediments based on measurements in Lake Ohakuri. Environmental Science and Technology, 19: 231-238. PMID:22296009. doi:10.1021/es00133a002. 
Ali AA, Carcaillet C, and Bergeron Y. 2009. Long-term fire frequency variability in the eastern Canadian boreal forest: the influences of climate vs. local factors. Global Change Biology, 15: 12301241. doi:10.1111/j.1365-2486.2009.01842.x.

Austin-Smith P, and Bowes S. 2000. Tantramar dykeland wildlife habitat strategy. New Brunswick Department of Resources and Energy, Fredericton, New Brunswick.

Barr SM, White CE, and Hamilton MA. 2007. Lower Coverdale and Gaytons: middle Devonian and possibly older anorthosite-ferronorite, gabbro, and quartz monzonite intrusions in southeastern New Brunswick. Atlantic Geology, 43: 163-179. doi:10.4138/5647.

Blaauw M, and Christen JA. 2011. Flexible paleoclimate age-depth models using an autoregressive gamma process. Bayesian Analysis, 6: 457-474. doi:10.1214/ba/1339616472.

Booth RK, Brewer S, Blaauw M, Minckley TA, and Jackson ST. 2012. Decomposing the mid-Holocene Tsuga decline in eastern North America. Ecology, 93: 1841-1852. PMID:22928413. doi:10.1890/ 11-2062.1.

Boyle JF. 2000. Rapid elemental analysis of sediment samples by isotope source XRF. Journal of Paleolimnology, 23: 213-221. doi:10.1023/A:1008053503694.

Branchu P, and Bergonzini L. 2004. Chloride concentrations in Lake Tanganyika: an indicator of the hydrological budget? Hydrology and Earth Systems Science Discussions, 8: 256-265. doi:10.5194/ hess-8-256-2004.

Brännvall ML, Bindler R, Emteryd O, and Renberg I. 2001. Four thousand years of atmospheric lead pollution in northern Europe: a summary from Swedish Lake sediments. Journal of Paleolimnology, 25: 421-435. doi:10.1023/A:1011186100081.

Brunschön C, Haberzettl T, and Behling H. 2010. High-resolution studies on vegetation succession, hydrological variations, anthropogenic impact and genesis of a subrecent lake in southern Ecuador. Vegetation History and Archaeobotany, 19: 191-206. doi:10.1007/s00334-010-0236-4.

Caldwell CA, Canavan CM, and Bloom NS. 2000. Potential effects of forest fire and storm flow on total mercury and methylmercury in sediments of an arid-lands reservoir. Science of the Total Environment, 260: 125-133. PMID:11032121. doi:10.1016/S0048-9697(00)00554-4.

Canadian Council of Ministers of the Environment (CCME) (Ed.). 1999. Canadian environmental quality guidelines. Canadian Council of Ministers of the Environment, Hull, Quebec.

Chalmers R. 1895. Summary report on investigations of surface geology of southeastern New Brunswick and adjacent parts of Nova Scotia and Prince Edward Island. Annual Report No. 6. Geological Survey of Canada, Ottawa, Ontario.

Chmura GL, Coffey A, and Crago R. 2001. Variation in surface sediment deposition on salt marshes in the Bay of Fundy. Journal of Coastal Research, 17: 221-227.

Cohen AS. 2003. Paleolimnology: the history and evolution of lake systems. Oxford University Press, Oxford, UK.

Craw D, Falconer D, and Youngson JH. 2003. Environmental arsenopyrite stability and dissolution: theory, experiment, and field observations. Chemical Geology, 199: 71-82. doi:10.1016/S0009-2541 (03)00117-7. 
Davis DS, and Browne S. (Eds.). 2002. Natural history of Nova Scotia (Vol. 2). Nova Scotia Museum, Halifax, Nova Scotia.

Davison W. 1993. Iron and manganese in lakes. Earth-Science Reviews, 34: 119-163. doi:10.1016/ 0012-8252(93)90029-7.

Dixit SS, Dixit AS, Smol JP, Hughes RM, and Paulsen SG. 2000. Water quality changes from human activities in three northeastern USA lakes. Lake and Reservoir Management, 16: 305-321. doi:10.1080/07438140009354238.

Dummer TJB, Yu ZM, Nauta L, Murimboh JD, and Parker L. 2015. Geostatistical modeling of arsenic in drinking water wells and related toenail arsenic concentrations across Nova Scotia, Canada. Science of the Total Environment, 505: 1248-1258. PMID:24613511. doi:10.1016/j. scitotenv.2014.02.055.

Dunnington DW. 2011. Using paleolimnological methods to track late Holocene environmental change at Long Lake, New Brunswick-Nova Scotia border region, Canada. B.Sc. thesis, Acadia University, Wolfville, Nova Scotia. 93 p.

Dunnington DW, Spooner IS, White CE, Cornett RJ, Williamson D, and Nelson M. 2016. A geochemical perspective on the impact of development at Alta Lake, British Columbia, Canada. Journal of Paleolimnology, 56: 315-330. doi:10.1007/s10933-016-9919-x.

Dypvik H, and Harris NB. 2001. Geochemical facies analysis of fine-grained siliciclastics using Th/ $\mathrm{U}, \mathrm{Zr} / \mathrm{Rb}$ and $(\mathrm{Zr}+\mathrm{Rb}) / \mathrm{Sr}$ ratios. Chemical Geology, 181: 131-146. doi:10.1016/S0009-2541(01) 00278-9.

Englehardt PO. 2013. Lead accumulation in open water wet ecosystems in the border marsh region of New Brunswick and Nova Scotia. B.Sc. thesis, Acadia University, Wolfville, Nova Scotia. 96 p.

Engstrom DR, and Wright HE. 1984. Chemical stratigraphy of lake sediments as a record of environmental change. In Lake sediments and environmental history: studies in palaeolimnology and palaeoecology in honour of Winifred Tutin. Edited by EY Haworth, JWG Lund, and W Tutin. Leicester University Press, Leicester, UK. pp. 11-67.

Euliss NHJ, Wrubleski DA, and Mushet DM. 1999. Wetlands of the Prairie Pothole Region: invertebrate species composition, ecology, and management. In Invertebrates in freshwater wetlands of North America: ecology and management. Edited by DP Batzer, RB Rader, and SA Wissinger. John Wiley \& Sons, New York, New York. pp. 471-514. Available from pubs.er.usgs.gov/publication/85406.

Foisy M, and Prichonnet G. 1991. A reconstruction of glacial events in southeastern New Brunswick. Canadian Journal of Earth Sciences, 28: 1594-1612. doi:10.1139/e91-143.

Forster DR, Oswald WW, Faison EK, Doughty ED, and Hansen BCS. 2006. A climatic driver for abrupt mid-Holocene vegetation dynamics and the hemlock decline in New England. Ecology, 87: 2959-2966. PMID:17249218. doi:10.1890/0012-9658(2006)87[2959:ACDFAM]2.0.CO;2.

Fraser DC. 1961. Organic sequestration of copper. Economic Geology, 56: 1063-1078. doi:10.2113/ gsecongeo.56.6.1063.

Gallagher L, Macdonald RW, and Paton DW. 2004. The historical record of metals in sediments from six lakes in the Fraser River Basin, British Columbia. Water, Air, and Soil Pollution, 152: 257-278. doi:10.1023/B:WATE.0000015349.25371.af. 
Ganong WF. 1903. The vegetation of the Bay of Fundy salt and diked marshes: an ecological study; contributions to the ecological plant geography of the Province of New Brunswick, No. 3. Botanical Gazette, 36: 161-186. doi:10.1086/328394.

Garcia E, and Carignan R. 1999. Impact of wildfire and clear-cutting in the boreal forest on methyl mercury in zooplankton. Canadian Journal of Fisheries and Aquatic Sciences, 56: 339-345. doi:10.1139/f98-164.

Garrison PJ, and Wakeman RS. 2000. Use of paleolimnology to document the effect of lake shoreland development on water quality. Journal of Paleolimnology, 24: 369-393. doi:10.1023/A:1008107706726.

Glew JR. 1989. A new trigger mechanism for sediment samplers. Journal of Paleolimnology, 2: 241-243. doi:10.1007/BF00195474.

Glew JR, Smol JP, and Last WM. 2001. Sediment core collection and extrusion. In Tracking environmental change using lake lediments. Edited by WM Last and JP Smol. Kluwer Academic Publishers, Dordrecht, the Netherlands. pp. 73-105.

Gregory BRB, Reinhardt EG, Macumber AL, Nasser NA, Patterson RT, Kovacs SE, et al. 2017. Sequential sample reservoirs for Itrax-XRF analysis of discrete samples. Journal of Paleolimnology, 57: 287-293. doi:10.1007/s10933-017-9944-4.

Guyard H, Chapron E, St-Onge G, Anselmetti FS, Arnaud F, Magand O, et al. 2007. High-altitude varve records of abrupt environmental changes and mining activity over the last 4000 years in the Western French Alps (Lake Bramant, Grandes Rousses Massif). Quaternary Science Reviews, 26(19-21): 2644-2660. doi:10.1016/j.quascirev.2007.07.007.

Hudgins A. 1999. Report on the Taylor Village Claim Group. New Brunswick Department of Natural Resources and Energy, Minerals and Energy Division, Fredericton, New Brunswick, Assessment File 475256 .

Jetté H, and Mott RJ. 1995. Vegetation and climate of Maritime Canada at 6000 years BP: a synthesis. Géographie physique et Quaternaire, 49: 141-162. doi:10.7202/033034ar.

Johnson SC. 2008. Bedrock geology of pre-Carboniferous basement inliers in the Coal Creek, Canaan River, and Thorne Brook areas, southeastern New Brunswick platform. In Abstracts 2008: exploration, mining and petroleum New Brunswick. Edited by SA Merlini. New Brunswick Department of Natural Resources Minerals, Policy and Planning Division, Sussex, New Brunswick. p. 39.

Kalnejais LH, Martin WR, Signell RP, and Bothner MH. 2007. Role of sediment resuspension in the remobilization of particulate-phase metals from coastal sediments. Environmental Science and Technology, 41: 2282-2288. PMID:17438776. doi:10.1021/es061770z.

Kelly EN, Schindler DW, Louis VLS, Donald DB, and Vladicka KE. 2006. Forest fire increases mercury accumulation by fishes via food web restructuring and increased mercury inputs. Proceeding of the National Academy of Sciences of the USA, 103: 19380-19385. PMID:17158215. doi:10.1073/ pnas.0609798104.

Koinig KA, Shotyk W, Lotter AF, Ohlendorf C, and Sturm M. 2003. 9000 years of geochemical evolution of lithogenic major and trace elements in the sediment of an alpine lake-the role of climate, vegetation, and land-use history. Journal of Paleolimnology, 30: 307-320. doi:10.1023/A:1026080712312. 
Kylander ME, Ampel L, Wohlfarth B, and Veres D. 2011. High-resolution X-ray fluorescence core scanning analysis of Les Echets (France) sedimentary sequence: new insights from chemical proxies. Journal of Quaternary Science, 26: 109-117. doi:10.1002/jqs.1438.

Lepane V, Varvas M, Viitak A, Alliksaar T, and Heinsalu A. 2007. Sedimentary record of heavy metals in Lake Rõuge Liinjärv, southern Estonia. Estonian Journal of Earth Science, 56: 221-232. doi:10.3176/earth.2007.03.

Loder AL, Mallory ML, Spooner I, McLauchlan C, Englehardt PO, McLellan N, et al. 2016. Bioaccumulation of lead and arsenic in gastropods inhabiting salt marsh ponds in coastal Bay of Fundy, Canada. Water, Air, and Soil Pollution, 227: 75. doi:10.1007/s11270-016-2774-6.

MacDonald A, and Clowater R. 2005. Natural ecosystem connectivity across the Chignecto Isthmus: opportunities and challenges. Canadian Parks and Wilderness Society, Ottawa, Ontario [online]: Available from cpawsnb.org/images/upload/ChignectoFinalVersionJune06v2.pdf.

Mackie EAV, Lloyd JM, Leng MJ, Bentley MJ, and Arrowsmith C. 2007. Assessment of $\delta^{13} \mathrm{C}$ and $\mathrm{C} / \mathrm{N}$ ratios in bulk organic matter as palaeosalinity indicators in Holocene and Lateglacial isolation basin sediments, northwest Scotland. Journal of Quaternary Science, 22: 579-591. doi:10.1002/jqs.1081.

Masscheleyn PH, Delaune RD, and Patrick WH Jr. 1991. Effect of redox potential and pH on arsenic speciation and solubility in a contaminated soil. Environmental Science and Technology, 25: 14141419. doi:10.1021/es00020a008.

Meyers PA, and Lallier-Vergés E. 1999. Lacustrine sedimentary organic matter records of Late Quaternary paleoclimates. Journal of Paleolimnology, 21: 345-372. doi:10.1023/A:1008073732192.

Meyers PA, and Teranes JL. 2001. Sediment organic matter. In Tracking environmental change using lake sediments: volume 2: physical and geochemical methods. Edited by WM Last and JP Smol. Kluwer Academic Publishers, Dordrecht, the Netherlands. pp. 239-269.

Misiuk B. 2014. A multi-proxy comparative paleolimnological study of anthropogenic impact between first and second lake, Lower Sackville, Nova Scotia. B.Sc. thesis, Acadia University, Wolfville, Nova Scotia. 67 p.

Mitsch WJ, and Gosselink JG. 2015. Wetlands. 5th edition. John Wiley \& Sons, New York, New York.

Mott RJ, Walker IR, Palmer SL, and Lavoie M. 2009. A late-glacial-Holocene palaeoecological record from Pye Lake on the eastern shore of Nova Scotia, Canada. Canadian Journal of Earth Sciences, 46: 637-650. doi:10.1139/E09-034.

New Brunswick Department of Natural Resources and Energy. 2002. NR-7 metallogenic map of New Brunswick. New Brunswick Department of Resources and Energy, Fredericton, New Brunswick.

O'Driscoll NJ, Rencz AN, and Lean DRS. 2005. The biogeochemistry and fate of mercury in the environment. In Biogeochemical cycles of elements. Edited by $\mathrm{H}$ Sigel and R Sigel. CRC Press, Boca Raton, Florida, Vol. 43, pp. 221-235.

O'Driscoll NJ, Canário J, Crowell N, and Webster T. 2011. Mercury speciation and distribution in coastal wetlands and tidal mudflats: relationships with sulphur speciation and organic carbon. Water, Air, and Soil Pollution, 220: 313-326. doi:10.1007/s11270-011-0756-2. 
Outridge PM, and Wang F. 2015. The stability of metal profiles in freshwater and marine sediments. In Environmental contaminants: using natural archives to track sources and long-term trends of pollution. Edited by JM Blais, MR Rosen, and JP Smol. Springer, Dordrecht, the Netherlands. pp. 35-60.

Railton JB. 1975. Post-glacial history of Nova Scotia. In Proceedings of the Nova Scotian Institute of Science. Edited by JG Ogden III, and MJ Harvey. Nova Scotian Institute of Science, Halifax, Nova Scotia, Volume 27, Supplement 3, pp. 37-42.

Rampton VN. 1984. NR-8 generalized surficial geology map of New Brunswick. New Brunswick Department of Resources and Energy, Fredericton, New Brunswick.

Reasoner MA. 1993. Equipment and procedure improvements for a lightweight, inexpensive, percussion core sampling system. Journal of Paleolimnology, 8: 273-281. doi:10.1007/BF00177859.

Reiche M, Lu S, Ciobotă V, Neu TR, Nietzsche S, Rösch P, et al. 2011. Pelagic boundary conditions affect the biological formation of iron-rich particles (iron snow) and their microbial communities. Limnology and Oceanography, 56: 1386-1398. doi:10.4319/1o.2011.56.4.1386.

Reimer PJ, Bard E, Bayliss A, Beck JW, Blackwell PG, Bronk Ramsey C, et al. 2013. IntCal13 and Marine13 radiocarbon age calibration curves 0-50,000 years cal BP. Radiocarbon, 55: 1869-1887. doi:10.2458/azu_js_rc.55.16947.

Rouillon M, and Taylor MP. 2016. Can field portable X-ray fluorescence (pXRF) produce high quality data for application in environmental contamination research? Environmental Pollution, 214: 255-264. PMID:27100216. doi:10.1016/j.envpol.2016.03.055.

Ryan RJ, and Boehner RC. 1994. Geology of the Cumberland Basin, Cumberland, Colchester and Pictou Counties, Nova Scotia. Nova Scotia Department of Natural Resources, Halifax, Nova Scotia.

Rydberg J. 2014. Wavelength dispersive X-ray fluorescence spectroscopy as a fast, non-destructive and cost-effective analytical method for determining the geochemical composition of small loose-powder sediment samples. Journal of Paleolimnology, 52: 265-276. doi:10.1007/s10933-014-9792-4.

Rydberg J, Rösch M, Heinz E, and Biester H. 2015. Influence of catchment vegetation on mercury accumulation in lake sediments from a long-term perspective. Science of the Total Environment, 538: 896-904. PMID:26363145. doi:10.1016/j.scitotenv.2015.08.133.

Schaller T, Moor HC, and Wehrli B. 1997. Sedimentary profiles of Fe, Mn, V, Cr, As and Mo as indicators of benthic redox conditions in Baldeggersee. Aquatic Sciences, 59(4): 345-361. doi:10.1007/BF02522363.

Schwab FE, and Daury RW. 1989. Incidence of ingested lead shot in Nova Scotia waterfowl (1973-2006). Wildlife Society Bulletin, 17: 237-240.

Scott DB, Frail-Gauthier J, and Mudie PJ. 2014. Coastal wetlands of the world: geology, ecology, distribution and applications. Cambridge University Press, Cambridge, UK.

Sharitz RA, and Batzer DP. 1999. An introduction to freshwater wetlands in North America and their invertebrates. In Invertebrates in freshwater wetlands of North America: ecology and management. Edited by DP Batzer, RB Rader, and SA Wissinger. John Wiley \& Sons, New York, New York. pp. 1-23. 
Shaw J, and Ceman J. 1999. Salt-marsh aggradation in response to late-Holocene sea-level rise at Amherst Point, Nova Scotia, Canada. Holocene, 9: 439-451. doi:10.1191/095968399668027869.

Shaw J, Gareau P, and Courtney RC. 2002. Paleogeography of Atlantic Canada 13-0 kyr. Quaternary Science Reviews, 21: 1861-1878. doi:10.1016/S0277-3791(02)00004-5.

Shaw J, Amos CL, Greenberg DA, O'Reilly CT, Parrott DR, and Patton E. 2010. Catastrophic tidal expansion in the Bay of Fundy, Canada. Canadian Journal of Earth Sciences, 47: 1079-1091. doi:10.1139/E10-046.

Spencer CN, Gabel KO, and Hauer FR. 2003. Wildfire effects on stream food webs and nutrient dynamics in Glacier National Park, USA. Forest Ecology and Management, 178: 141-153. doi:10.1016/S0378-1127(03)00058-6.

Spooner I, Stolze S, Martin B, Robichaud A, Herman T, Mockford S, et al. 2014. A 10,000-year record of environmental change from Blanding's turtle (Emydoidea blandingii) habitat at Pleasant River Fen, Nova Scotia, Canada. Wetlands, 34: 1145-1158. doi:10.1007/s13157-014-0573-7.

Stea RR. 1982. Properties, correlation, and interpretation of Pleistocene sediments in central Nova Scotia. M.Sc. thesis, Dalhousie University, Halifax, Nova Scotia. 215 p.

Stea RR, Boyd R, Costello O, Fader GBJ, and Scott DB. 1996. Deglaciation of the inner Scotian Shelf, Nova Scotia: correlation of terrestrial and marine glacial events. Geological Society, 111: 77-101. doi:10.1144/GSL.SP.1996.111.01.06.

Stevenson AL, Scheuhammer AM, and Chan HM. 2005. Effects of nontoxic shot regulations on lead accumulation in ducks and American woodcock in Canada. Archives of Environmental Contamination and Toxicology, 48: 405-413. PMID:15719196. doi:10.1007/s00244-004-0044-x.

Stuiver M, and Reimer PJ. 1993. Extended ${ }^{14} \mathrm{C}$ data base and revised CALIB $3.0{ }^{14} \mathrm{C}$ age calibration program. Radiocarbon, 35(1): 215-230. doi:10.1017/s0033822200013904.

Sullyman O. 2003. Historical records of metal contamination in the Tantramar Salt Marshes, Nova Scotia. Atlantic Universities Geoscience Conference Program, Halifax, Nova Scotia. pp. 268-269.

Terry DBS. 2011. The effects of water level fluctuations and sediment resuspension on water quality at Tupper Lake, Nova Scotia. B.Sc. thesis, Acadia University, Wolfville, Nova Scotia. 92 p. [online]: Available from openarchive.acadiau.ca/cdm/singleitem/collection/HTheses/id/700/rec/12.

Tylmann W, Łysek K, Kinder M, and Pempkowiak J. 2011. Regional pattern of heavy metal content in lake sediments in northeastern Poland. Water, Air, and Soil Pollution, 216: 217-228. PMID:21423334. doi:10.1007/s11270-010-0529-3.

Weiss D, Shotyk W, Boyle EA, Kramers JD, Appleby PG, and Cheburkin AK. 2002. Comparative study of the temporal evolution of atmospheric lead deposition in Scotland and eastern Canada using blanket peat bogs. Science of the Total Environment, 292: 7-18. PMID:12108447. doi:10.1016/ S0048-9697(02)00025-6.

Wersin P, Höhener P, Giovanoli R, and Stumm W. 1991. Early diagenic influences on iron transformation in a fresh-water lake sediment. Chemical Geology, 90: 233-252. doi:10.1016/0009-2541(91) 90102-W.

Wetzel RG. 1983. Limnology. Saunders, St. Louis, Missouri. 
White HE. 2012. Paleolimnological records of post-glacial lake and wetland evolution from the Isthmus of Chignecto region, eastern Canada. M.Sc. thesis, Acadia University, Wolfville, Nova Scotia. 141 p. [online]: Available from openarchive.acadiau.ca/cdm/singleitem/collection/Theses/id/645/rec/80.

Young DR, and Jan TK. 1977. Fire fallout of metals off California. Marine Pollution Bulletin, 8: 109112. doi:10.1016/0025-326X(77)90133-3. 